Article

\title{
Adaptive Cycle as a Tool to Select Resilient Patterns of Rural Development
}

\author{
Rosanna Salvia ${ }^{\dagger} * *$ and Giovanni Quaranta ${ }^{\dagger}$ \\ Department of Mathematics, Computer Science and Economics, University of Basilicata, \\ Campus di Macchia Romana, Potenza 85100, Italy; E-Mail: giovanni.quaranta@unibas.it \\ $\dagger$ These authors contributed equally to this work. \\ * Author to whom correspondence should be addressed; E-Mail: rosanna.salvia@unibas.it; \\ Tel.: +39-0971-205411.
}

Academic Editor: Tan Yigitcanlar

Received: 18 June 2015 / Accepted: 10 August 2015 / Published: 14 August 2015

\begin{abstract}
Changes in agriculture, including simultaneous intensification and abandonment, have significantly shaped the evolution of rural areas. The assessment of resilience in agricultural systems could provide insights into the ability of many rural areas to survive and regain competitiveness following disturbances. The aim of this study is to use the adaptive cycle heuristic as a diagnostic tool to study dynamics of change in two agricultural sectors (durum wheat/sheep and goat farming) in the Basilicata region of Southern Italy over the last seventy years. The heuristic was applied through a participatory approach in a community of stakeholders who have conceived, in collaboration with researchers, the Manifesto "Let's Think Basilicata" as a regional instrument of analysis and a laboratory of ideas and development of proposals. Despite some methodological difficulties, the adaptive cycle heuristic proved useful to describe processes of change in the socio-ecological system and could have enormous potential in shaping policy instruments for rural areas. However, much greater research is needed, both in terms of theory and methodology, before policy impacts on resilience in socio-ecological systems can be fully understood.
\end{abstract}

Keywords: adaptive cycle; socio-ecological resilience; agricultural socio-ecological system; rural policies; stakeholder participation; participatory approach; social learning 


\section{Introduction}

Agriculture, understood as a multi-functional activity that connects man and the environment and gives rise to coupled human and natural systems [1], is experiencing an era of rapid change and growing uncertainty. Agricultural systems are facing a series of threats, including climate change, land degradation, price volatility and intensification processes, which put their long-term sustainability into question. Many areas of the world are facing the abandonment of agricultural activities in rural areas. The phenomenon is extremely complex both in terms of the nature of driving forces, which determine the rate of abandonment of agricultural activities, and in terms of its social, economic and environmental effects. While in Mediterranean agro-ecosystems the abandonment of rain-fed agriculture is accompanied by forest encroachment at higher altitudes and to agriculture intensification in plains [2-4], in the former Soviet Union et al. [5], on the other hand, land abandonment is shaped by unequal power relations between rural dwellers and investors and closely interlinked with the land grabbing phenomenon. In terms of the effects of farmland abandonment on biodiversity, research results are far from conclusive. Parody et al. [6], for example, studying the relationship between landscape changes and number of species, question more critical positions which tend to characterize land abandonment and afforestation mostly as a threat for biodiversity because they usually go together with landscape homogenization and have negative effects for open-habitat species of conservation value [7].

The intertwined dynamics between land abandonment/intensification of agricultural activities could be understood as the two faces of the same food regime arrangement, where food regimes are intended as forms of geo-political ordering and related forms of accumulation, and function as vectors of power [8]. The current corporate food regime, which is based on the politics of neo-liberalism, gives preference to the price form, intensifies competition, disempowers farmers and empowers agribusiness, across the world. The results of the capitalist mode of production underlying the corporate food regime have been a mass exodus from farming in the North and South, social exclusion, through the appropriation of resources (material, intellectual, and spiritual), the privatisation of public goods, land dispossession and concentration [8] and accelerated biophysical contradictions [9]. In this scenario, also, the "large versus small" debate weakens and the contemporary phenomenon of land grabbing and the negative assumptions that are made about the consequences of large-scale agriculture for food security and employment fade in significance [10].

It is, however, important to highlight that alongside the idea that agriculture can potentially lead to the degradation of natural resources if poorly managed [11], it is also important to consider that agriculture plays an important role of defence and guardianship of territories [12].

The dynamics of the agricultural sector, and of rural territories as a whole, are closely connected to the ability of both to manifest resilience. Resilience is considered as the amount of change a system can undergo in the face of a series of threats and still retain the same controls on function and structure while maintaining options to develop $[13,14]$. Given the amount of change seen in modern times, many rural areas have had to redefine their role and functions to ensure their survival. Policies, both at local and higher levels, play a vital role in this process and face the challenge of responding to economic instabilities whilst safeguarding ecological functions in rural areas. Other essential elements in this process are the role of local actors in defining and implementing policies and grassroots actions aimed at local development with an emphasis on bottom-up approaches. According to Weis [9], there has been a 
sufficient increase in awareness and activism at both the level of production and consumption to suggest that the inconsistencies of the capitalist agricultural model are becoming much more evident. Pelling et al. [15] argue that the quality of relationships within organisations and policy regimes are central to adaptive capacity as they can provide spaces for individuals to interact, communicate, experiment and learn from each other in ways that can surpass formal processes within policy and organisational settings. Walsh-Dilley et al. [16] extend the analysis to include the idea of power and power relations and delineate a social justice approach to conceptualising resilience, which supports the empowerment of local actors and wherein equity is essential for building and maintaining resilient systems. Particularly of interest in the power relations debate, in fact, is the idea that resilience is a contested process, which can see many different actors in a given community having differing or opposing ideas on what constitutes desirable resilience.

In the last decade, significant progress has been made to interdisciplinary investigation and modelling of coupled social-ecological systems (SES) [17]. Resilience theory, which proposes five heuristics to describe patterns of change (adaptive cycles, resilience, panarchy, transformability, and adaptability), has been suggested as a means of capturing dynamics in complex SES and as a useful framework since it accounts for system recovery and adaptation to exposures [18]. The resilience theory suggests that key system components, and the focal scales at which they interact, are often best identified through strategies that co-involve experts and stakeholders who understand the system from different scales and perspectives [14,19].

The extent to which policies can prove effective in helping rural territories resist external disturbances and contribute to their resilience is yet to be fully determined [20]. Studies on the resilience of social-ecological systems have shown that while SES are likely to spend by far the majority of their time in periods of gradual change, shaped by persistent stresses, these will be interrupted by shorter, episodic disturbances, whose timing and origin cannot be foreseen, and may reconfigure the system [21]. Persistent stresses differ from episodic disturbances in that they tend to have impacts that are more predictable; this is the case of the threat of the persistent stress of agricultural intensification on environmental or production outcomes. Episodic disturbances, or shocks, are sudden and highly unpredictable and can lead to system transformation [11]. In resilient agricultural systems, disturbances have the potential to create opportunities for innovation and for new pathways of development [22], whilst in a vulnerable system, even small disturbances may cause significant adverse social consequences $[23,24]$. In that respect, as outlined by Jerneck and Olsson [25], it should be recognised that the implicit normative assumption of resilience to preserve the system and thus resist changes could represent a contradiction, especially when it is applied to ecological systems closely linked with social systems such as agriculture. Preventing major changes to the ecological system could imply that the social system needs to change radically or even sever its links with the ecological system.

In this study, we present the results of a research carried out by the University of Basilicata in collaboration with local representatives from various sectors of production of the Basilicata region of Southern Italy, which is considered a model of the dynamics at play in rural territories. In 2011, the Manifesto "Let's Think Basilicata" ("Manifesto Pensiamo Basilicata") was released in support of the formulation of regional policies and was intended to be a tool to promote initiatives for local and rural development. We tested the explanatory usefulness of the resilience theory for the Basilicata 
agricultural social-ecological system by applying the adaptive cycle as a diagnostic tool to explore the dynamics and trajectories of change in the SES. This approach also allowed us to evaluate the performance of social, economic and social capital, which are subject to the same dynamics. The aim of this work was firstly, to test the effectiveness of the heuristic model of adaptive cycles in the diagnosis of the regional context and, secondly, to test the usefulness of this heuristic in fostering social learning and better defining policies and actions that meet local needs.

The work is structured as follows; after a review of the literature on the use of the adaptive cycle, the characteristics of the Basilicata region and the methodology adopted are described; subsequently, we analysed and discussed the results and, finally, we drew our conclusions.

\section{The Adaptive Cycle}

The adaptive cycle is a heuristic model developed by Holling [26], within the field of ecology, and is used to describe the life cycle of complex adaptive systems. Holling [26] proposes a four-phase adaptive cycle model where a system slowly grows (exploitation phase), accumulates wealth for a sustained length of time (conservation phase), collapses (release phase), and rapidly reorganizes (reorganization phase), enabling it to grow either in the same or a different configuration [27].

Transitions between phases in the adaptive cycle are determined by its three main dimensions, potential, connectedness and resilience. Potential is described as the resources available to the system e.g., environmental, economic and social capital [26]. Connectedness is described as the strength of internal connections within the system that influence internal processes and determine its sensitivity to outside perturbations [27]. Since the levels of potential and connectedness change during the four phases of the cycle, the heuristic proposes that each phase can be distinguished based on their relative levels. A system's resilience can increase or decrease across the four phases of the adaptive cycle in relation to both potential and connectedness.

Although the notion of an adaptive cycle at the outset was developed as a useful metaphor for describing change in ecological systems, it has since evolved by incorporating theory from social and economic sciences and has proven useful for analysing how economic, social and social-ecological systems change throughout time [28,29]. Nevertheless, a deeper examination of sociocultural contexts and power relation might help identify fundamental variations in different social-ecological systems dynamics [30].

In the field of evolutionary economics and economic geography, Simmie and Martin [31] applied the adaptive cycle heuristic to regional economies. In the context of regional economies, the authors describe potential as including the skills and competences of individual firms and local workers, institutional forms, and physical and soft infrastructures (such as business and work cultures). Connectedness is described as relating to the level of interdependency among local firms (including supply inputs, divisions of labour, labour mobility, etc.) and the strength of local networks, such as networks of trust, formal and informal business associations. The study found that a regional economy's capacity to deal with internal or external disturbances would depend on the innovative capacity of existing local firms and the ability to establish new firms, both of which would be dependent on such factors as access to credit and venture capital, institutional innovation and the degree of willingness of workers to re-skill [31]. 
The adaptive cycle heuristic has also been applied to studying changes in social-ecological systems in various case studies [28,32,33]. However, these studies have sought to analyse the dynamics of one or more phases in the adaptive cycle whilst there remains very few examples in the literature of case studies that analyse the adaptive cycle as a whole. Such examples include Allison and Hobbs [34], who studied the resilience and capacity for renewal of a Western Australia agricultural system and Beier et al. [35], who studied forest management and the impacts of governance over land management in Alaska. Vang Rasmussen [36] applied the adaptive cycle heuristic to describe change in Sahelian land use systems and to develop conceptual means to account for system recovery and adaptation to exposures based on information obtained from extensive interviews and surveys at the group and household level. There are examples in the literature of studies that have found some systems do not adhere to the adaptive cycle model completely [37-39]. However, the great majority of case studies have found the heuristic proved an important tool for explaining changes in SES, especially when seeking to better understand specific phases within the cycle $[28,32,33,40,41]$.

Some of these studies have focused specifically on agricultural systems, examining the role of dependencies and interactions between the various subsystems of SES at different spatial scales and across domains [11,42]. Darnhofer et al. [11] assessed farm's resilience by considering each subsystem as having its own long-term adaptive cycle and assessing the influence of interactions with other subsystems, scales (i.e., local, national and international) and domains (i.e., ecological, social and economic dynamics). Campbell and Fairweather [42] use the New Zealand kiwifruit subsystem as a case study which shows the role international market forces and/or domestic policy changes can have on subsystems and highlights the need to link multiple spatial scales and players, what Gunderson and Holling [27] describe as "panarchy", into bigger and more complex depictions of overall dynamics in SES.

There have been few studies that attempt to quantitatively assess the connectedness and the potential properties to describe specific phase transitions in social-ecological systems. Abel et al. [28], described connectedness and potential in social-ecological systems in terms of capital and defined five subcategories (social, human, natural, physical, and financial capital) that could be assessed based on interpretations of case studies in regional SES in Zimbabwe and Australia. In another study, Nkhata et al. [43] employed trust and commitment as proxies for potential, while they defined connectedness as the degree to which actors in social relationships are linked. Daedlow et al. [29] attempted to develop in a social system indicators to differentiate potential and connectedness et al. All three studies found that assessing the properties of potential and connectedness remained a challenge when applying the adaptive cycle and highlighted the need for the greater inclusion of disciplinary social science theories to describe transitions between various system stages in social systems.

Most studies applying the adaptive cycle heuristic to SES use dynamic models [13,37], ecological or socioeconomic variables [34,35] or retrospectively qualitative reasoning [44-46].

\section{Materials, Methods and Sources of Information}

The analysis of Basilicata agriculture using the adaptive cycle heuristic was carried out through a participatory action research approach. Whyte [47] describes participatory action research as involving the active participation of stakeholders in the organization or community under study with professional 
researchers throughout the entire research process, from the initial design to the final presentation of results and discussion of their action.

The reconstruction of the causal links between the different historical events in the region and outcomes in terms of the resilience of social-ecological systems was based on a considerable amount of sources and data that retain, however, a certain degree of subjectivity [28,29]. To deal with this, we have relied on the direct involvement of stakeholders. The stakeholders were carefully selected to be representative of the regional production system, with representatives of both small and medium-sized farms and large firms that are already integrated in the market. The stakeholders also cover a wide age-range to ensure the broadest representation possible in the interpretation of causal links. Fifteen meetings involving about 60 stakeholders of the Manifesto "Let's Think Basilicata" were held from 2010-2014. The stakeholders represented four broad categories, namely farming, food processing, tourism and artisanal activities. The age ranged from 23 to 72 years old, the stakeholder selection was quite gender balanced, with a slightly higher percentage of men. The meetings were conceived as informal round table and the group discussions were recorded and shared among participants for agreement on their contents.

The identification of the various phases of the adaptive cycles was first carried out by the research group, on the basis of documentary sources and an analysis of the relevant literature. The initial research was then put to stakeholders to arrive at the definitive version, which reports two examples: the adaptive cycle of the durum wheat sector and that of goat and sheep farming, which are the most important agricultural sectors in the region.

The period chosen was the late 1940 s to the present day for two reasons; firstly, because the reconstruction of historical memory of local actors could easily cover this period and, secondly, because it marked the departure from traditional agriculture towards significant modernisation.

An initial approximate analysis of the phases of the adaptive cycle in the SES was carried out by tracking macro changes in both sectors through examining changes in land use, in the case of durum wheat, and numbers of livestock, in the case of sheep and goat farming, as well as total number of farms present. The evaluation of the dimensions, potential, connectedness and resilience was carried out using the criteria reported in Table 1, both for the documentary research and for stakeholder discussions.

Following Abel et al. [28] who argued that capital (e.g., human capital and financial capital) captures both potential and connectedness, the criteria have been identified by combining the components that may identify whether economic, social and natural capital are well or poorly developed at rural community level [48] with behaviour-based indicators of resilience within agro ecosystems [49].

More specifically, SES dynamics were described in terms of accumulation and releases of social, natural, and economic capital. Included in the definition adopted of social capital were social networks, levels of interaction between community members such as trust, relationships, conflict resolution processes, engagement of young and old people, learning and communication pathways, cooperation, bonding and bridging capital [50], and human capital. Strong capital guarantees a high level of potential, just as, conversely, weak capital signals an incapacity for the SES for adaptation, transformation, and overall responsiveness to changes, thus influencing the system's degree of resilience. Connectedness refers to the dynamic relationships between elements within a system and between systems across spatial and temporal scales. High connectedness implies a diversity of 
relationships between components, whereas low connectedness implies a dearth; strong connectedness makes a system rigid, whereas weak connectedness gives it flexibility. In an agroecosystem, it is desirable to have a high number of weak connections [49]. Criteria associated with the different capital and the quality of capital (strong or weak) indicates the degree of connectedness. For example, an appropriate connectedness would be farmers collaborating with multiple suppliers and multiple outlets rather than just one, which is a criteria associated with strong economic capital.

Table 1. Criteria to assess potential, connectedness and resilience.

\begin{tabular}{|c|c|c|c|c|}
\hline & Growth/Exploitation & Conservation & Collapse/Release & Reorganization \\
\hline $\begin{array}{l}\text { Strongly } \\
\text { developed } \\
\text { social } \\
\text { capital }\end{array}$ & $\begin{array}{l}\text { Presence of tight-knit } \\
\text { communities, open dialogue } \\
\text { between stakeholders groups, } \\
\text { high diversity, investment in } \\
\text { educational infrastructure } \\
\text { and institutions, support for } \\
\text { social events in farming } \\
\text { communities and programs } \\
\text { for preservation of } \\
\text { local knowledge }\end{array}$ & $\begin{array}{l}\text { - Close interaction between } \\
\text { rural people } \\
\text { (tight-knit communities) } \\
\text { - Good communication between } \\
\text { stakeholders groups } \\
\text { - High diversity } \\
\text { - Investment in infrastructure } \\
\text { and institutions for the } \\
\text { education of children and } \\
\text { adults, support for social } \\
\text { events in farming communities, } \\
\text { programs for preservation of } \\
\text { local knowledge } \\
\text { - Continued presence of } \\
\text { indicators seen in } \\
\text { previous phase }\end{array}$ & $\begin{array}{l}\text { - High diversity } \\
\text { - Maintenance of heirloom } \\
\text { of elders, incorporation } \\
\text { of traditional cultivation } \\
\text { techniques with } \\
\text { modern knowledge } \\
\text { Continued investment in } \\
\text { educational infrastructure } \\
\text { and institutions } \\
\text { Continued support } \\
\text { for farming community } \\
\text { social programs and } \\
\text { for transfer of } \\
\text { traditional knowledge }\end{array}$ & $\begin{array}{l}\text { - Continued presence of } \\
\text { indicators seen in } \\
\text { previous phase } \\
\text { - Ability to organize into } \\
\text { grassroots networks and } \\
\text { institutions (co-ops, farmer's } \\
\text { markets etc.) } \\
\text { Extension and advisory } \\
\text { services for farmers; } \\
\text { collaboration between } \\
\text { universities, research centres, } \\
\text { and farmers; cooperation and } \\
\text { knowledge sharing between } \\
\text { farmers; record keeping; } \\
\text { baseline knowledge about the } \\
\text { state of the agro ecosystem }\end{array}$ \\
\hline $\begin{array}{l}\text { Weakly } \\
\text { developed } \\
\text { social } \\
\text { capital }\end{array}$ & $\begin{array}{l}\text { - Outmigration of } \\
\text { young people } \\
\text { - Poor communication } \\
\text { between stakeholders } \\
\text { groups } \\
\text { - Low diversity } \\
\text { - Poor Investment in } \\
\text { educational infrastructure } \\
\text { and institutions s, absence } \\
\text { of support for social } \\
\text { events in farming } \\
\text { communities and } \\
\text { programs for preservation } \\
\text { of local knowledge }\end{array}$ & $\begin{array}{l}\text { Continued presence of indicators } \\
\text { seen in previous phase }\end{array}$ & $\begin{array}{l}\text { - Low diversity } \\
\text { ho Maintenance of } \\
\text { engagement of elders, } \\
\text { No incorporation of } \\
\text { traditional cultivation } \\
\text { techniques with modern } \\
\text { knowledge } \\
\text { Poor Investment in } \\
\text { educational infrastructure } \\
\text { and institutions, absence } \\
\text { of support for social } \\
\text { events in farming } \\
\text { communities and } \\
\text { programs for } \\
\text { preservation of local } \\
\text { knowledge }\end{array}$ & $\begin{array}{l}\text { - Continued presence of } \\
\text { indicators seen in } \\
\text { previous phase } \\
\text { - Inability to organize into } \\
\text { grassroots networks and } \\
\text { institutions (e.g., co-ops and } \\
\text { farmer's markets etc.) } \\
\text { - Absence of Extension and } \\
\text { advisory services for farmers; } \\
\text { No collaboration between } \\
\text { universities, research centres, } \\
\text { and farmers; No cooperation } \\
\text { and knowledge sharing } \\
\text { between farmers; } \\
\text { - No record keeping; no } \\
\text { baseline knowledge about the } \\
\text { state of the agro ecosystem }\end{array}$ \\
\hline
\end{tabular}


Table 1. Cont.

\begin{tabular}{|c|c|c|c|c|}
\hline & Growth/Exploitation & Conservation & Collapse/Release & Reorganization \\
\hline $\begin{array}{l}\text { Strongly } \\
\text { developed } \\
\text { economic } \\
\text { capital }\end{array}$ & $\begin{array}{l}\text { Farmers earning a living wage } \\
\text { from agricultural activities, } \\
\text { diversified income sources, } \\
\text { diversified suppliers and } \\
\text { outlets for producers, low } \\
\text { dependency on subsidies, } \\
\text { reduced external inputs and } \\
\text { reliance on commodity markets } \\
\text { through a focus on local markets } \\
\text { and resources and shared } \\
\text { resources; preservation of soil and } \\
\text { water resources. }\end{array}$ & $\begin{array}{l}\text { - Continued presence of } \\
\text { indicators seen in } \\
\text { previous phase } \\
\text { - Planting multiple varieties } \\
\text { of crops rather than one, } \\
\text { keeping equipment for } \\
\text { various crops, getting } \\
\text { nutrients from multiple } \\
\text { sources, capturing water } \\
\text { from multiple sources }\end{array}$ & $\begin{array}{l}\text { Planting multiple varieties } \\
\text { of crops rather than one, } \\
\text { keeping equipment for } \\
\text { various crops, getting } \\
\text { nutrients from multiple } \\
\text { sources, capturing water } \\
\text { from multiple sources }\end{array}$ & $\begin{array}{l}\text { - High diversity } \\
\text { - Builds (does not deplete) soil } \\
\text { organic matter, recharges } \\
\text { water, little need to import } \\
\text { nutrients or export waste }\end{array}$ \\
\hline $\begin{array}{l}\text { Weakly } \\
\text { developed } \\
\text { economic } \\
\text { capital }\end{array}$ & $\begin{array}{l}\text { High dependency on limited } \\
\text { number on suppliers/outlets, high } \\
\text { dependency on external funding } \\
\text { (subsidies or remittances), } \\
\text { individualistic behaviour, low } \\
\text { diversity, poverty and debt, } \\
\text { depleted soil and water resources } \\
\text { and high rates of importing inputs }\end{array}$ & $\begin{array}{l}\text { - Continued presence of } \\
\text { indicators seen in previous } \\
\text { phases } \\
\text { - Planting few varieties of } \\
\text { crops rather than multiple, } \\
\text { keeping specialized } \\
\text { equipment for single crop, } \\
\text { getting nutrients from } \\
\text { single sources, capturing } \\
\text { water from single sources }\end{array}$ & $\begin{array}{l}\text { Planting few varieties of } \\
\text { crops rather than multiple, } \\
\text { keeping specialized } \\
\text { equipment for single crop, } \\
\text { getting nutrients from } \\
\text { single sources, capturing } \\
\text { water from single sources }\end{array}$ & $\begin{array}{l}\text { - Low diversity } \\
\text { Deplete soil organic matter, } \\
\text { not recharges water, high } \\
\text { need to import nutrients or } \\
\text { export waste }\end{array}$ \\
\hline $\begin{array}{l}\text { Strongly } \\
\text { developed } \\
\text { natural } \\
\text { capital }\end{array}$ & $\begin{array}{l}\text { Polyculture planting and } \\
\text { diversified cultivation } \\
\text { practices, crop rotation and } \\
\text { patchiness on managed and } \\
\text { unmanaged land, good water and } \\
\text { soil quality and availability }\end{array}$ & $\begin{array}{l}\text { Continued presence } \\
\text { of indicators seen in } \\
\text { previous period }\end{array}$ & $\begin{array}{l}\text { Controlled exposures to } \\
\text { disturbances in the form } \\
\text { of pest management } \\
\text { followed by selection of } \\
\text { plants showing greatest } \\
\text { signs of resistance }\end{array}$ & $\begin{array}{l}\text { - High diversity } \\
\text { - Good water and soil quality } \\
\text { and availability }\end{array}$ \\
\hline $\begin{array}{l}\text { Weakly } \\
\text { developed } \\
\text { natural } \\
\text { capital }\end{array}$ & $\begin{array}{l}\text { Monoculture, monobreeding, } \\
\text { low diversity, farm specialization } \\
\text { and landscape simplification, soil } \\
\text { and water resource degradation } \\
\text { and desertification }\end{array}$ & $\begin{array}{l}\text { Continued presence of } \\
\text { indicators seen in } \\
\text { previous phase }\end{array}$ & $\begin{array}{l}\text { Natural capital is vulnerable } \\
\text { to disturbances }\end{array}$ & $\begin{array}{l}\text { - Low diversity } \\
\text { - Soil degradation } \\
\text { - Desertification } \\
\text { - Salinization } \\
\text { - Poor water quality } \\
\text { and availability }\end{array}$ \\
\hline
\end{tabular}

Source: authors based on $[48,49]$.

Behaviour-based indicators of resilience incorporate the different phases of the adaptive cycle and can act as a barometer of overall resilience in that their presence suggests a resilient SES whilst their absence or disappearance suggests a loss of resilience and greater vulnerability to disturbances [49]. Indicators of strongly developed capital include high economic, social and ecological diversity, the development of hard and soft infrastructures and low dependency on external inputs and markets whilst indicators of weakly developed capital include low diversity, lack of infrastructures and high dependency on external inputs and markets. 


\section{Basilicata Region}

The Basilicata region (Figure 1), located in Southern Italy, has a population of 578,391 [51] and a surface area of around 9922 square $\mathrm{km}$. The region's geographical distance from the larger and more dynamic centres of the country, together with its mountainous terrain, has forever played a fundamental role in shaping processes of development and its economic and social growth [52]. For much of its history, the region has been marginalised from processes of development and over time has seen a growing rate of outmigration and a general impoverishment of its economic fabric. In the last twenty-three years (1991-2014), just under 32,137 people migrated out of the region [51]. Recent outmigration trends particularly involve young, highly educated people who cannot find suitable work to match their newly acquired skills. In recent years, the job market in Basilicata is showing worrying signs of crisis, the rate of unemployment is three points higher than national figures, standing at $15.2 \%$ in 2013 [53]. Youth unemployment and unemployment amongst women is even higher.

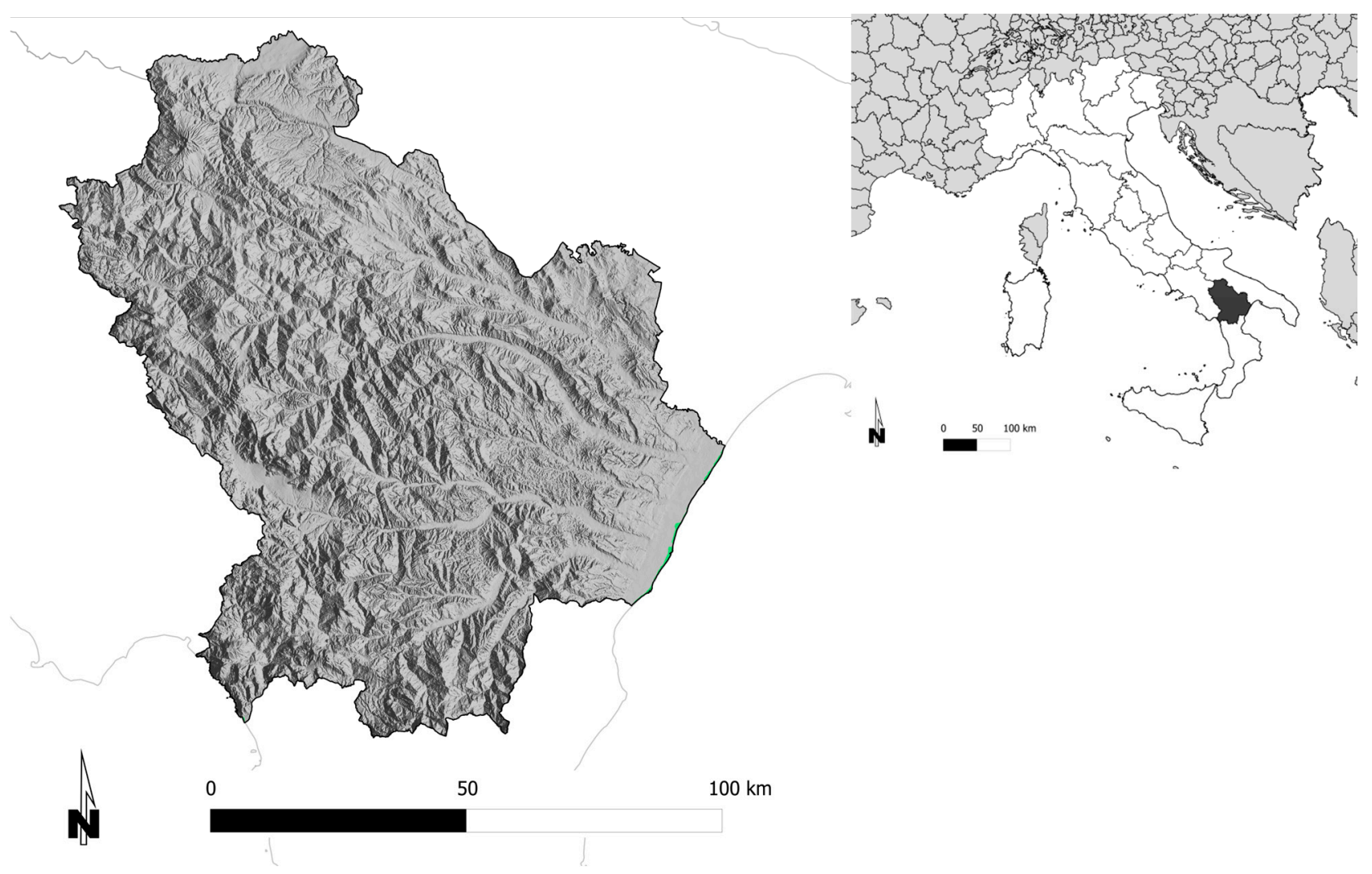

Figure 1. Basilicata region.

Despite the significant reduction in the number of farms in recent years, the weight of agriculture in the regional economy remains high, at 5.6\%. Agriculture provides 15,500 jobs in the region, of which $55 \%$ are salaried jobs, and accounts for $8 \%$ of regional employment [54].

The agricultural sector can be considered the cornerstone of the regional economy [52] with the durum wheat and the sheep and goats farming sectors playing a critical role in the total agricultural production. In fact, these two productive sectors represent over $25 \%$ of total saleable regional production [55]. In the durum wheat sector, data on farm distribution and surface area shows an increase from past years in the number of micro farms with a surface area below five hectares and, 
consequently, a reduction in the number of farms with a surface area above 20 hectares. In terms of legal structure, the majority of farms are privately owned by individuals, mostly farmed directly by the owner, and family run farms. The goat and sheep farms have an average number of 71 sheep and 33 goats, an increase in both cases from the figures of 2000, which were 41 and 22, respectively. The productive structure is centred upon milk and meat, although there are also specialized livestock farms that have breeds with higher productive capacity. Currently, this type of livestock farming is increasingly showing signs of taking root because the ancient practise of transhumance, which once guided livestock towards the plains, has ceased due to organisational problems and significant changes to the plains, which have been increasingly used for horticultural cultivation in recent decades. Production in the two sectors under study is, therefore, characterised by a high degree of fragmentation that positions them between family commercial farming and subsistent farming. These two sectors were chosen to be the focus of analysis in the Manifesto "Let's Think Basilicata" because of how diffused they are throughout the local territory, because of their importance in economic terms and in terms of employment, and, because they are the two sectors which are most exposed to disturbances from international markets and loss of competitiveness.

\section{Results}

\subsection{The Adaptive Cycle of Durum Wheat and Sheep and Goat Sector Farming}

The analysis of the results for both sectors was carried out jointly because the dynamics of each sector are comparable and because the level of integration between the two justifies a combination of the two. The two sectors share the same structural characteristics, small-scale production, and both are situated in highly competitive markets. The majority of the drivers of change are the same for both sectors. Where there are small differences, these have been highlighted.

Changes in land cover for durum wheat cultivation and sheep and goat farming, as well as changes in total numbers of farms in both sectors, were analysed in light on the dynamics that shaped social, economic and natural capital. The analysis of trends of the three dimensions, potential, connectedness and resilience, extrapolated from the trajectories of the three different types of capital, led to the identification of the adaptive cycle from 1940 to the present day for each of the two sectors. Table 2 shows the assessment of the three types of capital and dimensions carried out jointly by the stakeholders and research group. Starting with the criteria shown in Table 1, they first evaluated the three types of capital and, subsequently, based on the levels of the capital (strong or weak), evaluated the direction (high or low) of the three dimensions in each phase of the adaptive cycle. 
Table 2. Capital, potential, connectedness, and resilience assessment in each phase. Utilised land surface for cereals and farms. Number of sheep and goats.

\begin{tabular}{|c|c|c|c|c|c|c|c|c|}
\hline Phase & & Capital & & Potential & Connectedness & Resilience & $\begin{array}{c}\text { Utilised Land } \\
\text { Surface and } \\
\text { Farms } \\
\end{array}$ & $\begin{array}{l}\text { Number } \\
\text { of Sheep } \\
\text { and Goats }\end{array}$ \\
\hline & Social & Economic & Natural & & & & & \\
\hline $\begin{array}{c}\text { Reorganisation } \\
1940-1960\end{array}$ & Weak & Strong & Strong & High & Low & High & $\begin{array}{c}\text { From } 287,216 \\
\text { to } 201,221 \\
\text { hectares } \\
82,414 \text { farms }\end{array}$ & $\begin{array}{c}\text { From } \\
686,219 \text { to } \\
456,383 \\
\text { animals } \\
\end{array}$ \\
\hline $\begin{array}{c}\text { Exploitation } \\
1971-1981\end{array}$ & Weak & Strong & Strong & Low & High & High & $\begin{array}{c}\text { From } 230,111 \\
\text { to } 261,503 \\
\text { hectares } \\
\text { From } 65,861 \\
\text { to } 42,586 \\
\text { farms }\end{array}$ & $\begin{array}{c}\text { From } \\
501,238 \text { to } \\
430,279 \\
\text { animals }\end{array}$ \\
\hline $\begin{array}{c}\text { Conservation } \\
1981-2000\end{array}$ & Weak & Strong & Weak & High & High & Low & $\begin{array}{c}\text { From } 261,503 \\
\text { to } 201,425 \\
\text { hectares } \\
\text { From } 42,586 \\
\text { to } 29,991 \\
\text { farms }\end{array}$ & $\begin{array}{c}\text { From } \\
430,279 \text { to } \\
431,897 \\
\text { animals }\end{array}$ \\
\hline $\begin{array}{c}\text { Release New } \\
\text { reorganization? } \\
\text { 2000-today }\end{array}$ & Weak & Weak & Weak & Low & High & Low & $\begin{array}{c}\text { From } 201,425 \\
\text { to } 136,334 \\
\text { hectares } \\
\text { From } 29,991 \\
\text { to } 17,449\end{array}$ & $\begin{array}{c}\text { From } \\
431,897 \text { to } \\
321,809 \\
\text { animals }\end{array}$ \\
\hline
\end{tabular}

Source: authors, with the contribution of the stakeholders of Manifesto "Let's think Basilicata".

\subsubsection{Reorganization Phase (Late 1940-1960)}

At the end of the Second World War, Basilicata was in a deep depression. The greatest problem facing the region was land distribution. Vast estates owned by old families occupied much of the inland hilly areas. In many cases, these estates were farmed by families under sharecropping contracts. This work model was challenged when farm labourers began occupying the lands of large estate owners, which was to be the beginning of a popular movement for fairer land distribution [56]. After an initial violent confrontation where the people's movement was forcibly removed from the occupied land the Agrarian Reform Law was passed (L.n, 230/1950; L.n. 841/1950). The reform was aimed at the expropriation, transformation and reallocation of land in order to reach a fairer system of distribution, promote development and reduce the pressure of farm labourers. Following the reform, 59,000 hectares of land were expropriated in Basilicata and the old model of sprawling private estates was destroyed, paving the way for the spread of small independent farms [57]. However, after a promising start, the institutional bodies which had been set up for the purpose of implementing the profound changes needed for agrarian reform (overhaul of cropping plans, increased land reclamation works, mechanization, modernization of agricultural product processing industries, availability of 
finance to farmers, etc.) were gradually dismantled [58]. The reform, despite its noble and quite necessary aims, came at a time when the traditional rural farming society model was on the verge of becoming obsolete thanks to the advent of the industrial society [57].

After the Second World War, Italy went through an economic boom unlike anything ever seen before and, following an initial transition period, Italian industry grew exponentially whilst agriculture was increasingly marginalised. The factories and industries were concentrated in the historically wealthy North of Italy whilst the unskilled labour force was predominately located in the historically under-developed South of Italy. The result was a mass outmigration from rural areas of Southern Italy towards the promise of financial security in the industrialised cities of the north of the country. In Basilicata, population figures from 1909 to 2001 clearly show two trends; a steady out migration in the 1960s and 1970s of labour towards industrialised cities in the North of Italy and Central Europe and the simultaneous out migration from rural areas towards the two largest urban centres of the region (the largest city in the region registered a population increase of 200\% between 1931 and 1961). Both trends hit inland rural areas the hardest and would have long lasting economic and social impacts [59].

The phenomena of depopulation and the concentration of urban population were not only related to the plight of local economic development but were also determined by a crisis in the traditional world-view and by the emergence of new dynamic, and more integrated models of society, which broke from centuries-old social models. New values and increased awareness of life beyond the immediate local environment, as seen in the post war period, brought about rapid and profound change to the social and economic structure of rural communities that had for centuries remained substantially unchanged [60]. Historically, the small towns of the regional Apennines were established and prospered because of the fertile soil of the surrounding areas. Agriculture provided a model of social life, of land organization and of resource management, largely based on subsistence farming, with very limited economic, social and cultural growth [59]. After the war that archaic world was completed overturned by new and pervasive dynamics, which led to processes of deterritorialization [61], and forever changed the social, cultural and economic terms of reference. However, the region was still perceived as incredibly under-developed in relation to the country as a whole, Basilicata was described as "one big field" in the 1950s and the South as a "land without a city" [62]. Even by the late 1950s, Basilicata had a generally weak industry and agriculture still played a decisive role in the regional economy.

Social capital, therefore, underwent profound and radical change. Migration, urbanisation, adherence to the new lifestyle, dictated by industrial development, all eroded ancient customs and practices. The traditional organisational model of the rural family and the relationship that it has with agricultural activities was challenged.

Economic capital grows in this period despite the fact that agricultural produce was almost exclusively destined for local markets. Legislative intervention in the form of agrarian reform constituted a stimulus for absentee owners who were forced to intervene on land hitherto left abandoned in order to avoid expropriation under the new law. The result was an immediate increase in productivity and crop diversification [58]. The possibility for some family members to work outside the sector also provided extra economic resources to invest in farming. Productivity of land and labour began increasing.

Natural capital is high. The survival of traditional cropping practices, progressively accompanied by more intensive techniques, protects soil from erosion and ensures the correct management of water 
resources. Livestock farming models that are integrated with forage crop farming continues to be widespread and the practice of transhumance goes on unabated, helping keep the inland and valley areas strongly connected.

The assessment of the three types of capital reveals an overall high level of potential, despite the fact that social capital is undergoing a major reorganisation. The level of connectedness between the various components of the agricultural system (farms and input and output markets) remains low in the period. It is a period characterised by a profound transformation of the pre-existing agricultural structure and displays a good degree of resilience in the SES given the amount of change it has seen.

\subsubsection{The Phase of Exploitation (1971-1981)}

Social Capital: The migratory flows towards urban areas and industrialised cities, which began in the previous period, strongly influence life in small rural towns where historically tight knit communities, and close family ties are challenged further by processes of modernisation. The spread of mechanisation, which began in the previous period, reaches its peak in this period and has a significant effect on the organisation and modes of relationships in farming communities. The system of labour exchange, especially during harvest, is undermined by the spread of machinery. Jobs in factories and, even more so, in the public administration are seen as a means of upward social mobility and the role of the farmer, together with traditional knowledge (relationship between the agro-ecosystem), is profoundly challenged and socially marginalised. European subsidies to farmers weakens relationships within the community, favouring individualistic mind-sets and, more worryingly, create power networks in which agricultural associations play a prominent role in controlling European funding.

Economic Capital: The emergence of heavily industrialised areas through special interventions under the government initiative Fund for the South, established in 1950, gradually moved the centre of gravity of production towards industry and the service sector at the expense of agriculture [59]. In this period, agriculture sees technological innovations and new organisational processes that completely redefine the sector.

Among the principal drivers of change was the spread of mechanisation, increased public investment, the Italian government's entrance into the "Common European Market" and changes in Italy's wheat crop policy [58]. This period saw the subordination of local agriculture to newly emerged industrial, commercial and financial monopolies, whose sole interest lay in maximising profits by increasing production and squeezing margins far beyond sustainable levels. These monopolies exerted total control over the movement, sale and distribution of agricultural produce and products, farmers' access to credit, tax and investment policy and so forth [58]. The evolution and transformation of the regional workforce is evident from the data that shows, in the decade 1965-1975, the weight of agriculture significantly reduce from $54 \%$ to $39 \%$, with a loss of 31,000 employed in agriculture, while the tertiary sector sees an increase of 16,000 employees and industry recorded an increase of about 13,000 employees [57].

The reduction in numbers employed in agriculture is accompanied by the spread of mechanisation. From 1960 to 1990, regional data shows an increase in mechanisation of farming and a steady growth in the use of chemical fertilisers and pesticides. 
The drive for modernisation and increased productivity in the agricultural sector was largely driven by European Common Agricultural Policy (CAP). From 1962, when the COM (Common Organisation of Agricultural Markets) was introduced, to 1992, when the Mac Sharry reforms of CAP were brought in, the policy of price support to farmers and import tariffs helped greatly inflate agricultural production in terms of surface area, numbers of livestock and, most importantly, in terms of the intensification of production methods.

Natural Capital: In inland hilly areas particularly, there is a homogenisation and simplification of the landscape due to an increased practise of mono cropping. Broadly speaking the traditional closed-loop system, based on farming both crops and livestock on the same farm, is replaced by monoculture. Monoculture and mechanisation can be considered the principal factors that led to the destruction of traditional farming, soil, and water protection systems. Crop rotation and transhumance are marginalised. The choice of crop varieties and livestock breeds is determined by external market pressures and is based on achieving the highest productivity.

The impoverishment of natural and social capital, compared to an increase in economic capital, lead to identify the potential as low for this period. The connectedness of the SES instead is increasing due to the integration of both sectors in the market, widely promoted by policies active in this period. The resilience that the system manifests in the face of the changes underway continues to be high. Farms, both cereal and livestock, respond to changes by adapting their production and organisational systems.

\subsubsection{Conservation Phase (1981-2000)}

Social Capital: The dynamics seen in the first period of growth are consolidated in these two decades and are aggravated by further ageing of the farming community and a lack of generational change. Actions under the Leader initiatives, funded by the EU, are introduced in the territory, which are aimed at the recovery and preservation of traditional practises and knowledge.

Economic Capital: From 1992 on, when the Mac Sharry reforms are implemented, there is a constant decrease in financial aid to farmers under CAP although the agricultural sector remains largely subsidised. Growing consumer environmental awareness, the introduction of PGI (Protected Geographical Indication) and PDO (Protected Designation of Origin) labelling for agricultural products and regional subsidies for organic farming all help shape the agricultural sector in this period, however, they fail to achieve substantial change. Most of the agricultural sector continues to have undifferentiated production.

Natural Capital: Studies into land degradation and soil erosion features in Basilicata have shown that the principal drivers of degradation and erosion since the post war period are changes in precipitation patterns and some types of land use change that were largely the result of flawed regional application of agricultural policy [63]. The authors found that in Basilicata, the risk of land degradation is closely linked to the seasonality of rainfall events in relation to agricultural practices and that the clayey nature of the native soils leave them vulnerable to erosion, particularly following abandonment of cultivation and significant disturbances such as land remodelling [63]. In the last thirty years, land degradation has also accelerated in Basilicata due to specific CAP measures [64,65], notably Reg. EEC 1765/92 which provided subsidies to farmers of durum wheat based on the surface area of cultivation, thus incentivising the reclamation of bush and badlands for durum wheat cultivation and Reg. EEC 2078/92, which introduced new compulsory regulations regarding farmland set-aside, which led to the 
increased abandonment of low productivity land which was most commonly found on reclaimed badlands. The reclamation of badlands involved intensive restructuring of land, flattening of landforms, reduction of slope angles and removing top soil, which left much greater areas of soil exposed to processes of erosion [66]. The subsequent abandonment of these lands led to the appearance of many common features of remodelled land including rills, gullies, debris flows, mudflows, soil creep and occasionally small landslides [63].

Another important phenomenon in this period is the reduction of pastures and the subsequent expansion of forests, with high impacts in terms of biodiversity. Although pastures have been in reduction since the $1960 \mathrm{~s}$, linked to the abandonment of traditional sheep and goat farming practices, in the period 1984-2010, there was almost a 20\% increase in forest cover at the expense of mountain pasture land [67].

The potential in this phase continues to remain quite high but solely because of economic capital as a result of the support offered by CAP. The connectedness of the SES is very high due to the consolidation of relations of farms upstream and downstream. Only a small number of farms from either sector show the ability to adapt to the new possibilities provided by the differentiation offered by niche markets such as organic produce and typical local products, and continue with mass, undifferentiated production. The SES, therefore, shows a decreasing degree of resilience.

\subsubsection{Release Phase (2000-Present Day)}

Social Capital: The depopulation of rural communities caused by sky-high outmigration and population ageing has led to the breakdown of previously tight-knit community relationships. This is reflected in the absence of community-organised initiatives such as farmers' cooperatives. A continuation of the status quo would put the survival of farming and animal husbandry into question, despite policies in place for its conservation, which would result in the loss of a wealth of traditional knowledge in vast areas of the region.

Economic Capital: The decoupling of EU farming subsidies played an important role in shaping economic capital. The Fisher reform of 2003 ended the coupling of agricultural subsidies to production and also marked the entrance of European agricultural production into competitive global markets. The change in policy hit farms in Basilicata hard as many farms had to change their production substantially to meet the demands of the new market. The level of specialisation of production required led many farms to close. In the sheep and goat farming sector the beginning of the decline came a decade earlier, in the 1990s. Economic capital contracted significantly due to reduced profitability and a decrease in the assets value. The farms that remained faced exponentially increased production costs and low sale prices. In many cases, farms are too big for their actual production requirements and have such high fixed overheads that keeping the farm running because unsustainable.

Natural Capital: This period sees the progression of the phenomena already evident in the previous phase. Desertification, according to data from the National Atlas of the areas at risk of desertification [68], affects $30.4 \%$ of the region. The Atlas identifies various systems of degradation that contribute to the phenomenon including water erosion, deposition, urbanisation, salinization and drought. Soil erosion is the most pressing driver of desertification in the Basilicata region with just under $20 \%$ of the region's surface affected by processes of erosion. The expansion of forests at the expense of the pastures contributes to the loss of biodiversity of wide areas of the region. 
The assessment of the three types of capital, which shows a progressive deterioration, leads to the definition of potential as low for this phase. The various components of the SES are still strongly connected and locked in the network of relations established in the previous phases. Resilience is low overall, with few initiatives, either private or promoted by institutions, which attempt to break the current patterns and lead the system in the direction of positive change.

\section{Attempts of Re-Organisation}

Two initiatives were inspired by the Manifesto "Let's Think Basilicata", based on reflections on the adaptive cycles of the two sectors and the assessment of the greatest problems that have emerged for each sector.

For the durum wheat sector the project REACT - return and validation of traditional knowledge for the conservation of soil in the regional cereal growing areas - funded under Measure 124 "Cooperation for development of new products, processes and technologies "of the Rural Development Programme Basilicata 2007-2013 has been implemented. The initiative, involves approximately 1100 cereal farms, mainly family run farms, organised in two large cooperatives, as well as three research institutions, namely University of Basilicata, Agricultural Research Council and National Research Centre. In order to ensure widespread dissemination results, an association that is widely representative of regional cooperatives, has also been involved. The project has a clear objective to respond to criticalities in the regional cereal sector, or rather the progressive deterioration of both social and natural capital, by attempting to bring back durum wheat cultivation techniques that were used in the past. These alternative approaches are based on traditional local knowledge for soil conservation (e.g., seeding practices, minimum tillage, restoring furrows). The initiative proposes to assess the agronomic and technical/economic feasibility of introducing innovations to the sector, in the form of cultivation techniques from the past, adapted to the current production context. The aim of the initiative is to identify and evaluate methods that simultaneously reduce production costs and promote soil conservation. The initiative also aims to evaluate the effects of traditional techniques on production, both in terms of quantity and quality, and to develop guidelines for the creation of a collective trademark of ecological quality for the region's cereal farms that adopt soil conservation techniques.

In the sheep and goat farming sector, the cooperative "Ederum Lucanum" has been set up which counts forty breeders and carries the brand "Lamb of Lucania Dolomites." Since March 2010, the Lamb of Lucania Dolomites has been part of the traditional food products of the Basilicata region. The cooperative has allowed farmers to improve their profit margins, not only by reducing some costs of production and transportation, but also thanks to an increase in the price that they can sell to the market. Some big distributers have taken up the product, thanks to a deal between the cooperative and the supermarket chain Ipercoop.

\section{Discussion}

The aim of this study has been twofold. Firstly, to use the adaptive cycle heuristic in a community of stakeholders as a diagnostic tool to explore the dynamics and trajectories of change and to demarcate, through a participatory and inclusive approach, the distinct phases of the adaptive cycle in two important sectors for the agricultural economy of the Basilicata region (durum wheat and sheep 
and goat farming) in the period late 1940-2014. The study's first objective was pursued by analysing the dynamics that influence social, economic and natural capital. The study's second aim, was to analyse the responses gained within the same community of stakeholders in the light of the theory of the resilience of social-ecological systems and to test whether the heuristics adds value to understanding the functioning and directions of change [36].

The adoption of the adaptive cycle within the community of stakeholders proved extremely fruitful both as a useful tool to assess the resilience of agricultural sectors and, more generally, the rural territory and as a tool to increase knowledge and awareness across the board from single farmers to local actors at all levels. This is vitally important if we consider the importance of the social domain when applying resilience thinking to farming systems. Decision making on farms is under direct influence from humans and successful transformation, innovation, and/or effective pre-emptive action to threats and disturbances depends not only on shifting conditions in the farming system but also on how farmers perceive and conceptualize their farm's potential and limits, the risks emanating from economic, social or ecological changes, and the options at their disposal to face such change [11]. The ability to communicate and build knowledge is important also in light of the concepts of social learning as key to successful environmental management [69,70]. Reed et al. [70] define social learning as understanding that goes beyond the individual to be accepted within wider social units and communities through interactions between the actors of various social networks, e.g., planners, policy makers and non-governmental organizations (NGOs) interacting with scientific researchers, landowners and other local stakeholders to learn from one another and address complex problems.

What emerged from the discussion between stakeholders of "Let's Think Basilicata" was the recognition of the urgent need to find a common ground to share problems related to agriculture and to promote greater synergy between the various alternative approaches to the dominant mode of production which are starting to emerge. At the heart of stakeholder discussion was also the need to re-establish the cultural and social role of farmers and breeders, who have largely been subordinated and marginalised since the onset of modernity. The stakeholders, quite aside from the rhetoric of multi-functionality as it is defined by CAP, have seen in ecological and socially inclusive agriculture a way out from the flawed logic competitive accumulation based on a perverse concept of efficiency.

The valorisation of traditional knowledge and its return to principal production methods are not a nostalgic nod to the past but is about local farmers taking back their area of production and taking on all the forms of knowledge embedded in their local communities. The cooperative initiative promoted in the goat and sheep farming sector signals an important break from the individualistic mindset promoted by the prevailing food regime. The cooperative has been seen as a tool to mend those bonds that were broken by the logic of scale economies and as a tool to place itself in a stronger position in the hierarchy of agribusiness. Another important element to come out of discussions was the need for scientific research that can enhance diversity and develop complementary approaches, and which seeks to actively involve both farmers and researchers as equals in the research process.

The analysis of the two sectors carried out under "Let's Think Basilicata", which has led to significant reorganisation in both, certainly benefitted from the input offered by the various stakeholders in the project. Involving stakeholders from farms of varying sizes helped provide a wider variety of points of view. The largest farm owners were the most hesitant to abandon the productivity logic in favour of better quality products and processes and the most hesitant to embrace the 
cooperative mind set. The worsening of the economic crisis, which occurred during the project, certainly significantly contributed to redefining the objectives of this component of the production structure and reposition production towards sectors of the market which are more sheltered from international competition. The lack of any competitive advantage which had been gradually lost over time, helped also by the protection offered by EU policies, has in fact led small, medium-sized and large farms to see the need to differentiate their production and abandon individualistic behaviours.

The conceptualisation of the two systems in terms of the dynamics of capital has shown that the capacity to preserve systems under the influence of incremental changes, and therefore maintain a certain degree of resilience, can come at the expense of parts of the same system. In the exploitation phase, the impoverishment of social and natural capital did not inhibit farm's capacity to adapt to the rules imposed on the agricultural productive system by its adhesion to the productivist paradigm. Naturally, this process of adaptation deepened structural disparities and dichotomies already present in the regional production context, leaving the smallest farms increasingly marginalised. The process also proved unsustainable both in socio-economic and environmental terms. Both systems, in fact, have seen a progressive decline in the options available to them and find it increasingly more difficult to remove themselves from the adaptive cycle in which they were placed.

The processes of self-organisation the durum wheat and sheep and goat farming systems have displayed, similarly to findings of a study by Mamonova [71], represent an example of a successful rural adaptation in the settings when social and economic capital is very low, and both rest on the stakeholders becoming aware of the need to rethink and reframe the process of development in the context of economic, environmental and social sustainability.

A key element to emerge from the analysis of the dynamics of the capital is the identification of the feedback loops of identified adaptive responses would have produced on other elements of the system itself, identifying the link between the socio-economic and the ecological system [72].

Both initiatives under Manifesto "Let's Think Basilicata" act jointly on all three dimensions of the system, the economic, social and natural, based on the recognition that there is an inescapable link between the quality of the environmental matrix, economic performance and social vitality of rural areas. This result confirms other studies [69] that highlight how, many farmers have become aware of the uncertainty of their social and economic context as well as their vulnerability in a globalised and interconnected world. This perception translates into a much more interconnected view of the issues they face and their management choices now reflect this wider appreciation of the environmental and economic contexts.

The project on the durum wheat sector focuses on the diffusion of innovations, based on modernising traditional techniques. Local and traditional knowledge in the region is strongly undermined by the depopulation of rural areas and the lack of generational change in farms. Seeing as how local knowledge transfer to the use of natural resources and on environmental management practices has been shown to be an important adaptation tool [73], the innovations proposed aim to link environmental objectives to economic and social objectives.

The farms that have joined the project REACT signed up to play a demonstrative role in the local area as vehicles for the dissemination of innovation. It is now universally recognized that farmers' responses to policy and environmental changes can be related to how they are presented to them [74]. As every adaptation measure is mediated by culture, culturally informed approaches are needed to set 
up new measures. Cultural enquiry, for example through ethnographic research, can document knowledge, responses in behaviour and practices [75]. Resilience theory suggests that feedback loops between social and ecological processes acting at different spatial and temporal scales can constrain or enhance the potential for innovation within the system. Other studies suggest that the adoption of conservation practices is not contingent upon a simple or single factor such as economic profitability or effective government conservation legislation. Rather, landscape-scale adoption of conservation practices must be compatible with ecological, sociocultural, economic, and political aspects of systems at multiple scales [76].

Similarly, the response adopted in the sheep and goat sector is based on the ability to act simultaneously on the three dimensions, natural, economic and social. Acting on social capital, recognised as being extremely weak in the current release phase, by promoting the establishment of the sheep and goat farmers' cooperative, is the instrument through which to achieve not only higher profits but also rebuild relationships amongst farmers themselves and between farmers and the local territory.

The role of dynamics of social capital on the resilience of social-ecological systems is well documented in the literature. In particular, studies on grazing land socio-ecological systems show that the weakening of both the bonding and bridging social capital explains many dynamics of land degradation [77]. The relevant relationship between rural abandonment and woody plant encroachment is well documented by research studies carried out in the Pyrenees [78] and the Italian [79] and Swiss Alps [80] where the increased woody plant encroachment has been explained by the continued farm abandonment and demographic changes.

\section{Conclusions}

The analysis of the conception and development of the Manifesto "Let's Think Basilicata" confirms the potential of resilience thinking and the adaptive cycle heuristic, in particular, to constitute a framework capable of recognising dynamics and reciprocal relationships at play throughout time and space. The way the adaptive cycle heuristic was used within the Manifesto "Let's Think Basilicata" was in line with the thinking of Holling and Gunderson [21]. That is to say, the heuristic was used as a framework to develop a holistic and dynamic assessment of the three types of capital and as an instrument to interpret the events seen and their underlying causes, as well as the adaptation mechanisms put in place by the SES to counterbalance their effects, rather than a real theory in itself. This feature is seen to a greater extent in a participatory and inclusive dimension. The active involvement of stakeholders in the identification of the different phases of the adaptive cycle provided an opportunity for knowledge exchange and co-production. From this perspective, the inherent determinism of the adaptive cycle concept, which is one of the limitations that is associated with the use of this heuristic, is lessened by its ability to activate paths of real social learning, as has, interestingly, proved the case in this study. Herein lies the value added by the analysis carried out.

The use of dynamic analysis of the social, economic and natural capital as the key to interpret the various phases of the adaptive cycle of the two agricultural systems proved a powerful tool in analysing the relationships between resilience and sustainable development in rural territories. Resilience, in fact, could coexist with unsustainable patterns of rural development. The adhesion to the paradigm of modernisation came at the sacrifice of local values, accumulated knowledge, practices, 
traditions, production methods and cultural ways of life of rural communities, in particular those communities made up of agricultural family units. At the same time, the adoption of capital and their interrelations proved fundamental to the elaboration of adaptation strategies which were compatible with patterns of sustainability.

The adaptive cycle heuristic, despite some methodological difficulties highlighted previously in this study, remains useful to describe processes of change in rural socio-ecological systems. However, the identification of criteria for the assessment of the capital, and therefore the three dimensions, potential, connectedness, and resilience, must be coupled with a very careful selection of the stakeholders to be involved in the assessment in order to avoid one-sided interpretations that might be conditioned by power relations within the evaluation group. A thorough knowledge of the territory and its productive structure, as well as a balanced selection of stakeholders, allowed us to keep the inherent discretionary component of the methodology adopted to an absolute minimum. There could be enormous potential in adopting these instruments to help identify the needs of different territories and help the framing and implementation of rural policies. Future research is needed in terms of development, both operationally and in strictly scientific terms, into these instruments through ongoing and ex-post assessments of actions adopted by the SES. Lines of research concerned with the assessment of the impact of policy instruments on the resilience of social-ecological systems are still in their infancy and will require further studies to investigate both the methodological and theoretical dimension.

\section{Acknowledgments}

The present study was carried out within the framework of the EC-DG RTD, 7th Framework Research Programme (Theme ENV.2011.2.1.4-2), Behaviour of ecosystems, thresholds and tipping points, Project CASCADE (283068): CAtastrophic Shifts in drylands: how can we prevent ecosystem DEgradation? The financial support by the European Commission is greatly acknowledged.

\section{Author Contributions}

This paper is a result of a joint work. All components of the paper have been equally shared. All authors read and approved the final manuscript.

\section{Conflicts of Interest}

The authors declare no conflict of interest.

\section{References}

1. Liu, J.; Dietz, T.; Carpenter, S.; Alberti, M.; Folke, C.; Moran, E.; Pell, A.; Deadman, P.; Kratz, T.; Lubchenco, J.; et al. Complexity of coupled human and natural systems. Science 2007, 317, 1513-1516.

2. MacDonald, D.; Crabtree, J.R.; Wiesinger, G.; Dax, T.; Stamou, N.; Fleury, P.; Gutierrez Lazpita, J.; Gibon, A. Agricultural abandonment in mountain areas of Europe: Environmental consequences and policy response. J. Environ. Manag. 2000, 59, 47-69. 
3. Beilin, R.; Lindborg, R.; Stenseke, M.; Pereira, H.M.; Llausàs, A.; Slätmo, E.; Cerqueira, Y.; Navarro, L.; Rodrigues, P.; Reichelt, N.; et al. Analysing how drivers of agricultural land abandonment affect biodiversity and cultural landscapes using case studies from Scandinavia, Iberia and Oceania. Land Use Policy 2014, 36, 60-72.

4. Nainggolan, D.; De Vente, J.; Boix-Fayos, C.; Termansen, M.; Hubacek, K.; Reed, M. Afforestation, agricultural abandonment and intensification: Competing trajectories in semi-arid Mediterranean agro-ecosystems. Agric. Ecosyst. Environ. 2012, 159, 90-104.

5. Visser, O.; Mamonova, N.; Spoor, M. Oligarchs, megafarms and land reserves: Understanding land grabbing in Russia. J. Peasant Stud. 2012, 39, 899-931.

6. Parody, J.M.; Cuthbert, F.J.; Decker, E.H. The effect of 50 years of landscape change on species richness and community composition. Glob. Ecol. Biogeogr. 2011, 10, 305-313.

7. Robinson, R.A.; Sutherland, W.J. Post-war changes in arable farming and biodiversity in Great Britain. J. Appl. Ecol. 2002, 39, 157-176.

8. McMichael, P. Global development and the corporate food regime. Res. Rural. Sociol. Dev. 2005, 11, 265-299.

9. Weis, T. The accelerating biophysical contradictions of industrial capitalist agriculture. J. Agrar. Chang. 2010, 10, 315-341.

10. White, B.; Borras, S.M., Jr.; Hall, R.; Scoones, I.; Wolford, W. The new enclosures: Critical perspectives on corporate land deals. J. Peasant Stud. 2012, 39, 619-647.

11. Darnhofer, I.; Fairweather, J.; Moller, H. Assessing a farm's sustainability: Insights from resilience thinking. Int. J. Agric. Sustain. 2010, 8, 186-198.

12. McCarthy, J. Rural geography: Multifunctional rural geographies-Reactionary or radical? Prog. Hum. Geogr. 2005, 29, 773-782.

13. Carpenter, S.R.; Walker, B.; Anderies, M.J.; Abel, N. From metaphor to measurement: Resilience of what to what? Ecosystems 2001, 4, 756-781.

14. Walker, B.; Carpenter, S.R.; Anderies, J.M.; Abel, N.; Cumming, G.S.; Janssen, B.M.; Lebel, L.; Norberg, J.; Peterson, G.D.; Pritchard, R. Resilience management in social-ecological systems: A working hypothesis for a participatory approach. Conserv. Ecol. 2002, 6, Article 14.

15. Pelling, M.; High, C.; Dearing, J.; Smith, D. Shadow spaces for social learning: A relational understanding of adaptive capacity to climate change within organisations. Environ. Plann. A 2008, 40, 867-884.

16. Walsh-Dilley, M.; Wolford, W.; McCarthy, J. Rights for Resilience: Bringing Power, Rights and Agency into the Resilience Framework, 2013. Available online: http://www.acsf.cornell.edu/ Assets/ACSF/docs/collaborations/oxfam/R4R\%20Conceptual\%20Framework.pdf (accessed on 7 August 2015).

17. Binder, C.R.; Hinkel, J.; Bots, P.W.G.; Pahl-Wostl, C. Comparison of frameworks for analyzing social-ecological systems. Ecol. Soc. 2013, 18, Article 26.

18. Walker, B.H.; Gunderson, L.H.; Kinzig, A.P.; Folke, C.; Carpenter, S.R.; Schultz, L. A handful of heuristics and some propositions for understanding resilience in social-ecological systems. Ecol. Soc. 2006, 11, Article 13. 
19. Westley, F.; Carpenter, S.R.; Brock, W.A.; Holling, C.S.; Gunderson, L.H. Why systems of people and nature are not just social and ecological systems. In Panarchy: Understanding Transformation in Human and Natural Systems; Gunderson, L.H., Holling, C.S., Eds.; Island Press: Washington, DC, USA, 2002; pp. 103-120.

20. Schouten, M.A.H.; van der Heide, M.C.; Heijman, W.J.M.; Opdam, P.F.M. A resilience-based policy evaluation framework: Application to European rural development policies. Ecol. Econ. 2012, 81, 165-175.

21. Gunderson, L.H.; Holling, C.S.; Peterson, G.D. Surprises and sustainability: Cycles of renewal in the Everglades. In Panarchy: Understanding Transformations in Human and Natural Systems; Gunderson, L.H., Holling, C.S., Eds.; Island Press: Washington, DC, USA, 2002; pp. 315-332.

22. Berkes, J. Navigating Social-Ecological Systems: Building Resilience for Complexity and Change; Berkes, F., Colding, J., Folke, C., Eds.; Cambridge University Press: Cambridge, UK, 2003.

23. Adger, W.N. Vulnerability. Glob. Environ. Chang. 2006, 16, 268-281.

24. Ericksen, P.J. Assessing the Vulnerability of Food Systems to Global Environmental Change: A Conceptual and Methodological Review. In GECAFS Working Paper, 3; NERC-Centre for Ecology \& Hydrology; GECAFS International Project Office: Wallingford, UK, 2006.

25. Jerneck, A.; Olsson, L. Adaptation and the poor: Development, resilience and transition. Clim. Policy 2013, 8, 170-182.

26. Holling, C.S. Understanding the complexity of economic, ecological, and social systems. Ecosystems 2001, 4, 390-405.

27. Holling, C.S.; Gunderson, L.H. Resilience and adaptive cycles. In Panarchy: Understanding Transformations in Human and Natural Systems; Gunderson, L.H., Holling, C.S., Eds.; Island Press: Washington, DC, USA, 2002; pp. 25-62.

28. Abel, N.; Cumming, D.H.M.; Anderies, J.M. Collapse and reorganization in social-ecological systems: Questions, some ideas, and policy implications. Ecol. Soc. 2006, 11, Article 17.

29. Daedlow, K.; Beckmann, V.; Arlinghaus. R. Assessing an adaptive cycle in a social system under external pressure to change: The importance of intergroup relations in recreational fisheries governance. Ecol. Soc. 2011, 16, Article 3.

30. Cote, M.; Nightingale, A.J. Resilience thinking meets social theory situating social change in socio-ecological systems (SES) research. Progr. Hum. Geogr. 2012, 36, 475-489.

31. Simmie, J.; Martin, R. The economic resilience of regions: Towards an evolutionary approach. Camb. J. Reg. Econ. Soc. 2010, 3, 27-43.

32. Alcorn, J.B.; Bamba, J.; Masiun, S.; Natalia, I.; Royo, A.G. Keeping ecological resilience afloat in cross-scale turbulence: An indigenous social movement navigates change in Indonesia. In Navigating Social-Ecological Systems: Building Resilience for Complexity and Change; Berkes, F., Colding, J., Folke, C., Eds.; Cambridge University Press: Cambridge, UK, 2003; pp. 299-327.

33. Seixas, C.S.; Berkes, F. Dynamics of socialecological changes in a lagoon fishery in southern Brazil. In Navigating Social-Ecological Systems: Building Resilience for Complexity and Change; Berkes, F., Colding, J., Folke, C., Eds.; Cambridge University Press: Cambridge, UK, 2003; pp. 271-298.

34. Allison, H.E.; Hobbs, R.J. Resilience, adaptive capacity, and the "Lock-in trap" of the Western Australian agricultural region. Ecol. Soc. 2004, 9, Article 3. 
35. Beier, C.M.; Lovecraft, A.L.; Chapin, F.S. Growth and collapse of a resource system: An adaptive cycle of change in public lands governance and forest management in Alaska. Ecol. Soc. 2009, 14, Article 5.

36. Vang Rasmussen, L.; Reenberg, A. Collapse and recovery in Sahelian agro-pastoral systems: Rethinking trajectories of change. Ecol. Soc. 2012, 17, Article 14.

37. Cumming, G.S.; Collier, J. Change and identity in complex systems. Ecol. Soc. 2005, 10, Article 29.

38. Walker, B.H.; Lawson, R.L. Case Studies in Resilience: Fifteen Social-Ecological Systems across Continents and Societies. Available online: http://www.resalliance.org/1613.php (accessed on 2 April 2015).

39. Bunce, M.; Mee, L.; Rodwell, L.D.; Gibb, R. Collapse and recovery in a remote small island-A tale of adaptive cycles or downward spirals? Glob. Environ. Chang. 2009, 19, 213-226.

40. Brunk, G.G. Why do societies collapse? A theory based on self-organized criticality. J. Theor. Polit. 2002, 14, 195-230.

41. Cocks, K.D. Deep Futures: Our Prospects for Survival; University of New South Wales Press: Sydney, Australia, 2003.

42. Campbell, H.; Fairweather, J. The Development of Organic Horticultural Exports in New Zealand; AERU Research Report No. 238; Lincoln University: Lincoln, New Zealand, 1998.

43. Nkhata, A.B.; Breen, C.M.; Freimund, W.A. Resilient social relationships and collaboration in the management of social-ecological systems. Ecol. Soc. 2008, 13, Article 2.

44. Peterson, G. Political ecology and ecological resilience: An integration of human and ecological dynamics. Ecol. Econ. 2000, 35, 323-336.

45. Bohensky, E.L. Discovering resilient pathways for South African water management: Two frameworks for a vision. Ecol. Soc. 2008, 13, Article 19.

46. González, J.A.; Montes, C.; Rodríguez, J.; Tapia, W. Rethinking the Galapagos Islands as a complex social-ecological system: Implications for conservation and management. Ecol. Soc. 2008, 13, Article 13.

47. Whyte, W.F. Participatory Action Research; Sage: Los Angeles, CA, USA, 1991.

48. Wilson, G. Multifunctional "Quality" and Rural Community Resilience; Transactions of the Institute of British Geographers: Wiley-Blackwell, UK, 2010.

49. Cabell, J.F.; Oelofse, M. An indicator framework for assessing agroecosystem resilience. Ecol. Soc. 2012, 17, Article 18.

50. Kelly, C.; Ferrara, A.; Wilson, G.A.; Ripullone, F.; Nolè, A.; Harmer, N.; Salvati, L. Community resilience and land degradation in forest and shrubland socio-ecological systems: Evidence from Gorgoglione, Basilicata, Italy. Land Use Policy 2015, 46, 11-20.

51. ISTAT. Istituto Nazionale di Statistica, 2014. Available online: http://www.istat.it/ (accessed on 15 April 2015). (In Italian)

52. Salvia, R. L'agroalimentare della Basilicata nella prospettiva della liberalizzazione dei mercati. In Mezzogiorno-Agricoltura Processi Storici e Prospettive di Sviluppo Nello Spazio EuroMediterraneo; Franco Angeli: Milano, Italy, 2011; pp. 397-417. (In Italian)

53. Banca d'Italia. Economie Regionali, L'economia Della Basilicata; Numero 17; Banca d'Italia: Roma, Italy, 2014. (In Italian) 
54. Bitetti, F. L'economia Della Basilicata nel 2010; Centro Studi Unioncamere: Basilicata, Italy, 2011. (In Italian)

55. INEA. Annuario Dell'agricoltura Italiana; INEA: Roma, Italy, 2012; Volume LXVI, ISBN 978-88-814-5269-9. (In Italian)

56. Menichini, S.; Carvaggi, L. Paesaggi che Cambiano_Linee Guida per la Progettazione Integrate del Paesaggio Della Basilicata; Officina Edizioni: Roma, Italy, 2006. (In Italian)

57. Giura Longo, R. La Basilicata Moderna e Contemporanea; Edizioni del Sole: Napoli, Italy, 1992.

58. Sereni, E. Storia del Paesaggio Agrario Italiano; Laterza: Bari, Italy, 2007. (In Italian)

59. Giambersio, V. Le origini della questione urbana in Basilicata. In Quando Credevamo di Poter Rifare il Mondo; Labella, A., Lavorano, E.M., Eds.; Calice Editori: Rionero in Vulture, Italy, 2007. (In Italian)

60. Doria, R.; Lucania, M. L'Italie du Sud a Travers L'une de Ses Regions; "Basilicata" Supplemento al n.1: Basilicata, Italy, 1990. (In Italian)

61. Magnaghi, M. Il Progetto Locale; Bollati Boringhieri: Torino, Italy, 2000. (In Italian)

62. Fabbri, M. In "Potenza e Matera, la Questione Urbana in Basilicata" AA.VV.; Basilicata Editrice: Potenza, Italy, 1986. (In Italian)

63. Piccarreta, M.; Capolongo, D.; Boenzi, F.; Bentivenga, M. Implications of decadal changes in precipitation and land use policy to soil erosion in Basilicata, Italy. Catena 2006, 65, 138-151.

64. Rendell, H.M. Soil erosion and land degradation in southern Italy. In Desertification in Europe; Fantechi, R., Margaris, N.S., Eds.; Commission of European Communities: Brussels, Belgium, 1986; pp. 184-193.

65. Sonnino, A.; Colonna, N.; Sciortino, M. Evoluzione Delle Coltivazioni in Basilicata e Degrado del Territorio; In Proceedings of the Atti del II- Forum Internazionale Politiche europee per combattere la desertificazione nel bacino mediterraneo, Matera, Italy, 29-31 October 1998. (In Italian)

66. Phillips, C.P. The badlands of Italy: A vanishing landscape? Appl. Geogr. 1998, 18, 243-257.

67. Mancino, G.; Nolè, A.; Ripullone, F.; Ferrara, A. Landsat TM imagery and NDVI differencing to detect vegetation change: Assessing natural forest expansion in Basilicata, southern Italy. iForest 2014, 7, 75-84.

68. Costantini, E.A.C.; Urbano, F.; Bonati, G.; Nino, P.; Fais, A. Atlante Nazionale Delle Aree a Rischio di Desertificazione; INEA: Roma, Italy, 2007; p.108. (In Italian)

69. Geeson, N.; Quaranta, G.; Salvia, R.; Brandt, J. Long-term involvement of stakeholders in research projects on desertification and land degradation: How has their perception of the issues changed and what strategies have emerged for combating desertification? J. Arid Environ. 2015, 114, 124-133.

70. Reed, M.S.; Evely, A.C.; Cundill, G.; Fazey, I.; Glass, J.; Laing, A.; Newig, J.; Parrish, B.; Prell, C.; Raymond, C.; et al. What is social learning? Ecol. Soc. 2010, 15, Article 1.

71. Mamonova, N. Resistance or adaptation? Ukrainian peasants' responses to large-scale land acquisitions. J. Peasant Stud. 2015, 42, 1-28.

72. Daly, H.E. Steady-State Economics; Island Press: Washington, DC, USA; Covelo, CA, USA, 1991.

73. Berkes, F.; Colding, J.; Folke, C. Rediscovery of traditional ecological knowledge as adaptive management. Ecol. Appl. 2000, 10, 1251-1262. 
74. Nainggolan, D.; Termansen, M.; Fleskens, L.; Hubacek, K.; Reed, M.; de Vente, J.; Boix-Fayos, C. What does the future hold for semi-arid Mediterranean agro-ecosystems? Exploring cellular automata and agent-based trajectories of future land-use change. Agric. Ecosyst. Environ. 2012, 159, 90-104.

75. Adger, W.N.; Barnett, J.; Brown, K.; Marshall, N.; O’Brien, K. Cultural dimensions of climate change impacts and adaptation. Nat. Clim. Chang. 2013, 3, 112-117.

76. Atwell, R.C.; Schulte, L.A.; Westphal, L.M. Linking resilience theory and diffusion of innovations theory to understand the potential for perennials in the U.S. Corn Belt. Ecol. Soc. 2008, 14, Article 30.

77. Kizos, T.; Detsis, V.; Iosifides, T.; Metaxakis, M. Social capital and social-ecological resilience in the Asteroussia Mountains, southern Crete, Greece. Ecol. Soc. 2014, 19, Article 40.

78. Gartzia, M.; Alados, C.L.; Pérez-Cabello, F. Assessment of the effects of biophysical and anthropogenic factors on woody plant encroachment in dense and sparse mountain grasslands based on remote sensing data. Prog. Phys. Geogr. 2014, 38, 201-217.

79. Motta, R.; Morales, M.; Nola, P. Human land-use, forest dynamics and tree growth at the treeline in the Western Italian Alps. Ann. For. Sci. 2006, 63, 739-747.

80. Gellrich, M.; Baur, P.; Koch, B.; Zimmermann, N.E. Agricultural land abandonment and natural forest re-growth in the Swiss mountains: A spatially explicit economic analysis. Agric. Ecosyst. Environ. 2007, 118, 93-108.

(C) 2015 by the authors; licensee MDPI, Basel, Switzerland. This article is an open access article distributed under the terms and conditions of the Creative Commons Attribution license (http://creativecommons.org/licenses/by/4.0/). 